\title{
INVESTIGATION OF BACILLUS THURINGIENSIS PLASMID INSTABILITY AND ITS EFFECT ON THE SYNTHESIS OF CRYSTALS
}

\section{ABSTRAGT}

In order to explore plasmid instability in $B t$, four $B t$ strains belonging to two $B t$ subspecies were cultured at $42^{\circ} \mathrm{C}$ for 9 days. HD1 and QBT376 belong to subspecies kurstaki, while H14 and QBT218 belong to subspecies israelensis. Results showed $100 \%$ crystal loss for H14 and QBT218, while $76 \%$ and $90 \%$ crystal loss for HD1 and QBT376, respectively, showing that cry-carrying plasmids are more stable in Bt kurs. than in Bt isr.. HD1, QBT376, and QBT218 cured clones showed significant protease activity compared to their non-cured counterparts. Microscopic observation revealed the delay of sporulation for high number of HD1 and QBT376 cryclones, while the absence of spores in several H14 and QBT218 cry- clones. Spo-cry- clones of Bti strains had irregular elongated cell shape. Kinetics/day of plasmid curing for H14 and QBT218 showed H14 to have higher pBtoxis plasmid stability. The number of vegetative cells in Bti strains increased with the increase of curing period. As an attempt to create hybrid Bt strains, cry1Aa gene was extracted to transform cured and noncured strains

\section{OBJEGTIVES}

1- Study the effect of the growth at high

temperature on plasmid stability in Bacillus thuringiensis.

2- Study of the effect of the plasmid loss on the

\section{Bacillus thuringiensis crystal synthesis.}

\section{LCERAURE REVIEW}

Bt is a rod-shaped, facultative aerobic, motile $\mathrm{Gram}^{+}$, spore-forming bacterium (Beena et al., 2019). It is the most used microbial pesticide and bio-insecticide due to its production of protein crystals responsible for its insecticidal action. It is considered among the safest and least environmentally damaging insecticidal products available (Raymond \& Federici, 2017). Over the last decade, several tests showed instability of Bt formulations due to high or low temperatures (Farghal \& Darwish, 1988; Moustafa et al., 2018). In addition, many cases of insect resistance to $B t$ were recorded (Kain et al., 2015; Tabashnik \& Carrière, 2015). Therefore, the need to evaluate plasmid instability of $B t$ before commercial production, in addition to finding novel strains, producing stable formulations, and creating $B t$ hybrids becomes crucial more than ever.

\section{Materials $\&$. Wethods}

Bacterial strains and their derivatives

Two Qatari Bt strains, QBT376 \& QBT218 that belong to 2 different $B t$ subspecies producing bipyramidal and spherical crystals, respectively were explored. HD1 \& H14 were used as reference strains.

\section{Plasmid curing}

1. An isolated colony of the four $B t$ strains was inoculated in LB Broth \& incubated at $42^{\circ} \mathrm{C}$ for $24 \mathrm{~h}$. Then, $100 \mu \mathrm{l}$ of the culture was transferred to fresh LB broth. This step was repeated for 8 days.

2. On the $9^{\text {th }}$ day, the culture was serially diluted, spread on LB agar and left overnight at $30^{\circ} \mathrm{C}$.

3. Then,100 single isolated colonies from each strain were transferred to T3 agar and milk-agar plates.

\section{Exploration of crystal formation}

Light microscope (100x magnification) was used to study the crystal forms.

\section{Exploration of cry gene content by PCR} Lep2A/2B \& Dip2A/2B primers were used in PCR experiments to explore cry-type genes.

\section{Extraction of cry1Aa gene}

Transformation of cured and non-cured Bt clones using Gene Pulser XcellTM Electroporation System

\section{RESULTS and DISCUSSION}

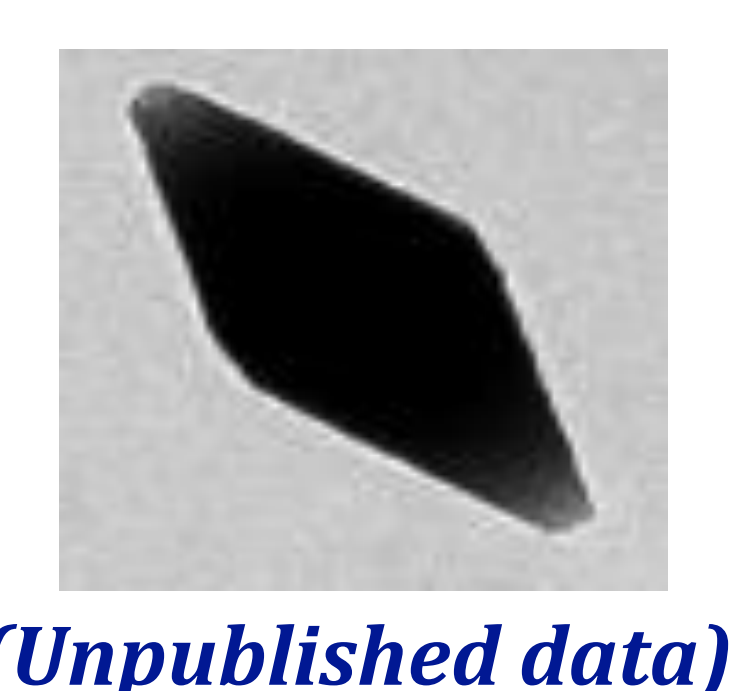

\section{Bacillus thuringiensis crystals}

Murst. vs. Isr.

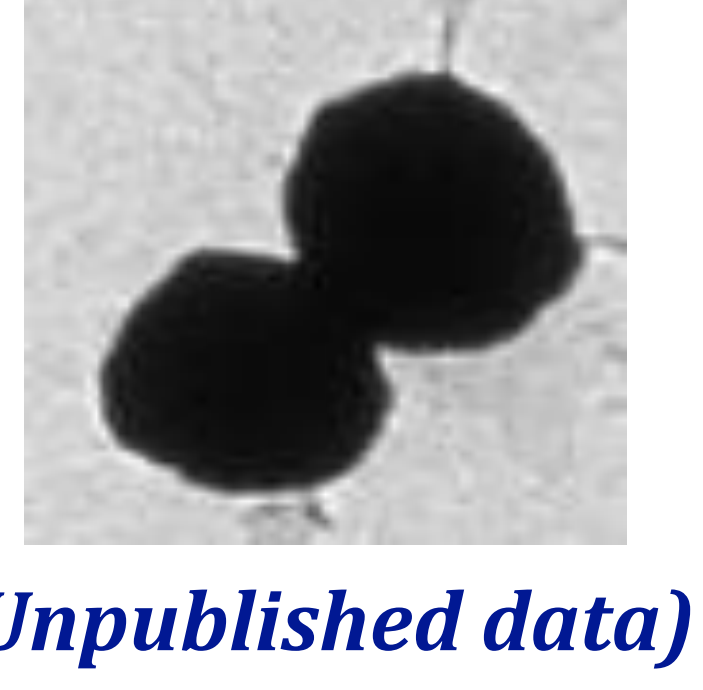

1. Plasmid instability affects Bacillus thuringiensis crystal formation, sporulation, and cell shape after 9 days growth at $42{ }^{\circ} \mathrm{C}$

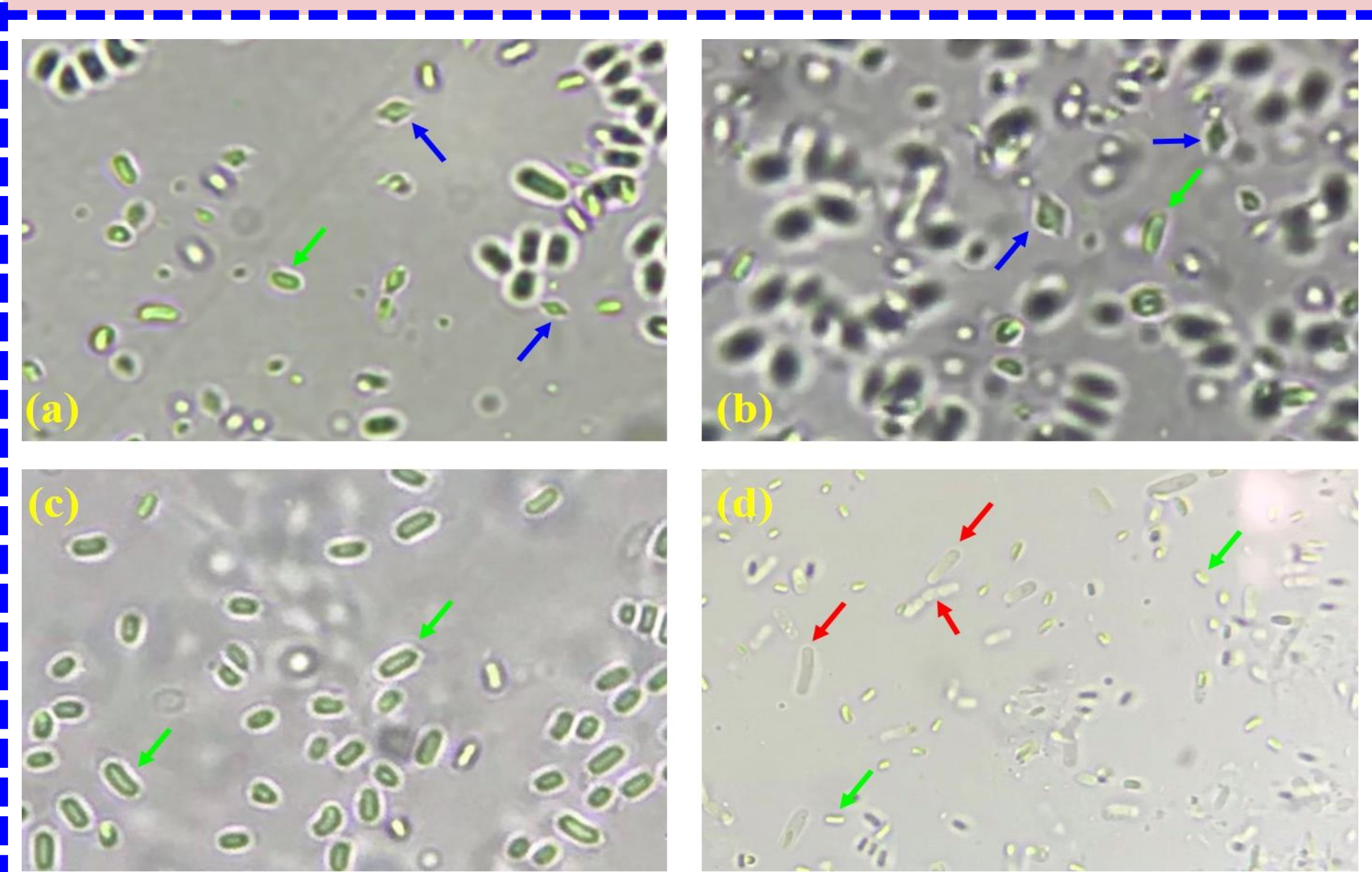

Spores, crystals, and vegetative cells from HD1 strain

(a): Spores and crystals of non-cured HD1; (b): spores
and crystals of cured HD1; (c): spores only of cured HD1;

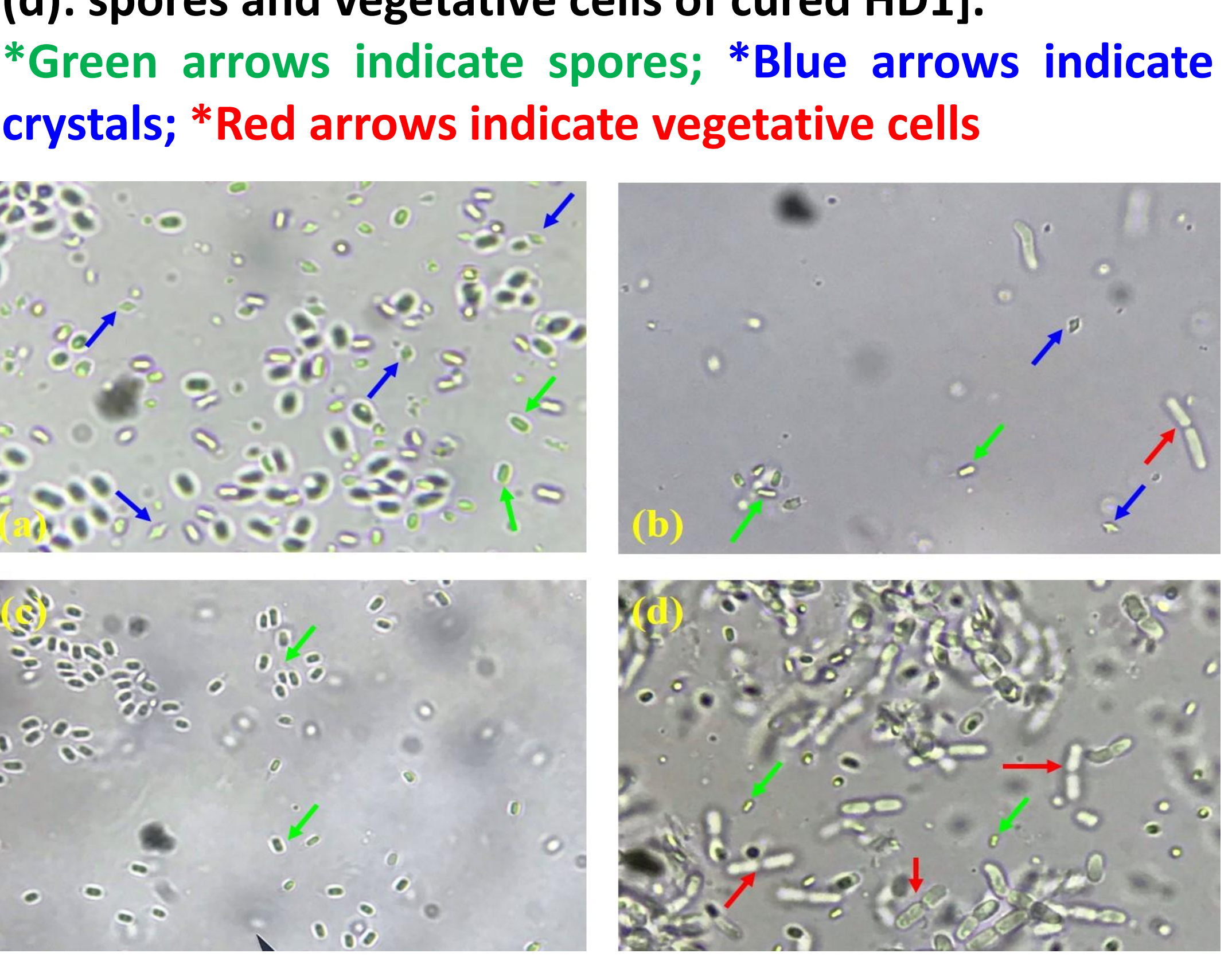

(a): spores and crystals of non-cured QBT376; (b): spores
(a) and crystals of cured QBT376; (c): spores only of cured QBT376; (d): spores and vegetative cells of cured QBT376].

tk. Plasmid instability was recorded as the absence of bipyramidal and cuboidal crystals under light microscope

\% Plasmid instability of the plasmids carrying cry genes of Btk

\begin{tabular}{|c|c|c|}
\hline Strain & HD1 (control) & QBT376 \\
\hline \% instability & $76 \%$ & $90 \%$ \\
\hline
\end{tabular}

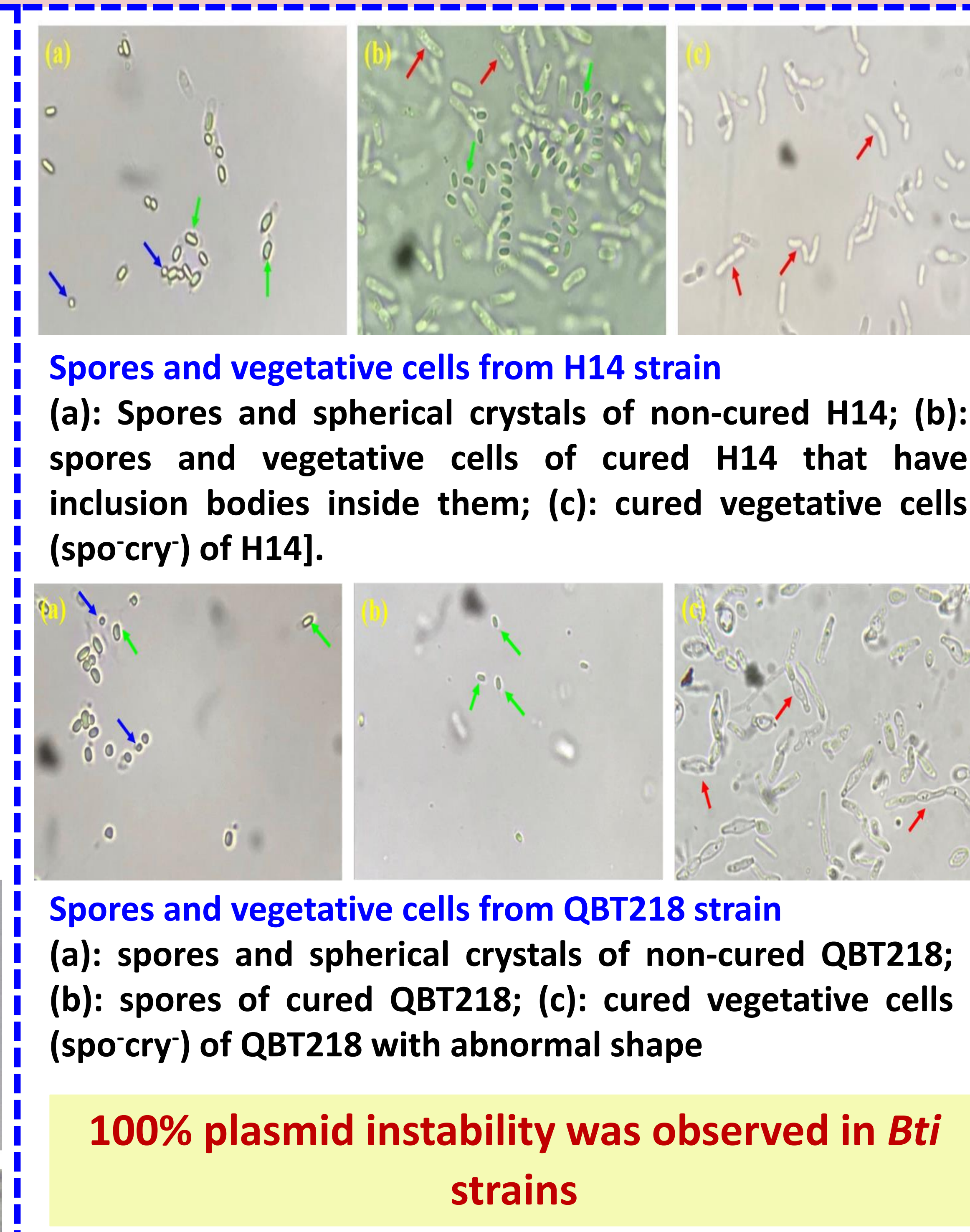

2. Kinetics of Btiloss of crystal formation, sporulation, and plasmid instability during 7 days growth at $42^{\circ} \mathrm{C}$ QBT218 than is in the reference strain H14

$100 \%$

$90 \%$

$80 \%$
$70 \%$

$50 \%$

$20 \%$

\% Plasmid instability H14

P Plasmid instability QBT218

3. Plasmid instability affects the production of proteases in $B t$

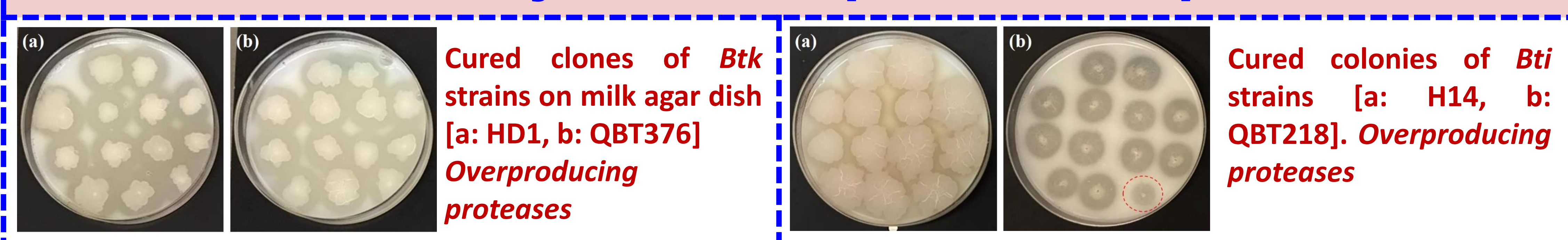

Depending on the Bt sub-species/strain, plasmid stability affects positively or negatively the secretion of proteases. Proteases are highly secreted in HD1, QBT376, and QBT218.

\begin{tabular}{|c|c|c|c|c|c|c|c|}
\hline \multicolumn{3}{|c|}{$\begin{array}{l}\text { Distance between the edge of the } \\
\text { bacterial colony }(\mathrm{mm})\end{array}$} & \multirow{3}{*}{$\begin{array}{l}\text { Estimation of } \\
\text { the Protease } \\
\text { activity of } B t k \\
\text { strains after } 9 \\
\text { days of } \\
\text { plasmid curing } \\
\text { at } 42^{\circ} \mathrm{C}\end{array}$} & \multicolumn{3}{|c|}{$\begin{array}{l}\text { Distance between the edge of the } \\
\text { bacterial colony }(\mathrm{mm})\end{array}$} & \multirow{4}{*}{$\begin{array}{l}\text { Estimation of } \\
\text { the Protease } \\
\text { activity of } B t i \\
\text { strains after } 9 \\
\text { days of plasmic } \\
\text { curing at } 42^{\circ} \mathrm{C}\end{array}$} \\
\hline \begin{tabular}{|l|} 
Strains \\
\end{tabular} & $\begin{array}{l}\text { Non-cured } \\
\text { (control) }\end{array}$ & $\begin{array}{c}\text { Cured } \\
(\text { Mean } \pm \text { SD) }\end{array}$ & & Strains & $\begin{array}{l}\text { Non-cured } \\
\text { (control) }\end{array}$ & $\begin{array}{c}\text { Cured } \\
(\text { Mean } \pm \text { SD) }\end{array}$ & \\
\hline HD1 & $3.00 \pm 0.00$ & $4.60 \pm 0.94$ & & $\mathrm{H}$ : & & & \\
\hline QBT376 & $4.00 \pm 0.00$ & $4.11 \pm 1.19$ & & QBT218 & 1.75 & 4.8 & \\
\hline
\end{tabular}

4. During plasmid loss, some mutants lose cry gene carrying plasmids, others still retain the plasmid and its cry gene

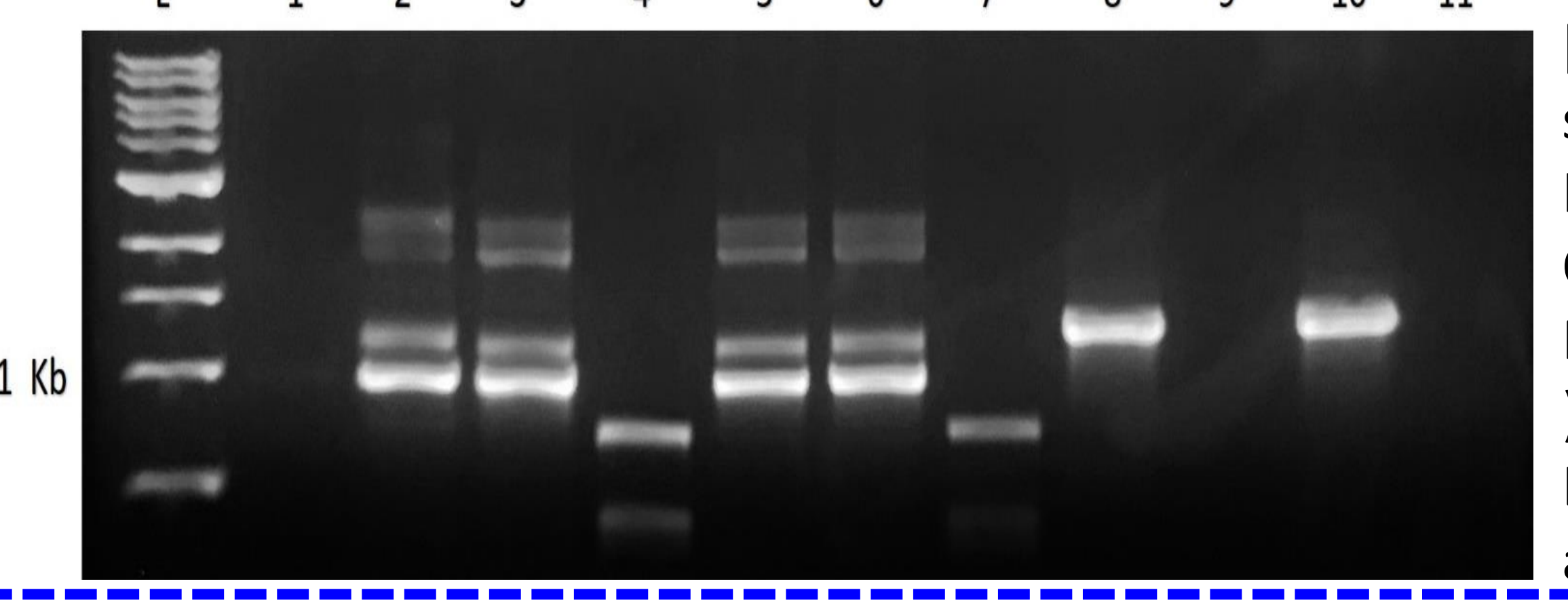
and crystals of cured HD1; (c): spores only of
(d): spores and vegetative cells of cured HD1]

In Bti, pBtoxis plasmid is more unstable is
5. Transfer of ery genes by electroporation to plasmid eured Bacllus thuringlensis mutants

A proposed solution to fight insect resistance to $B t$ is the creation of hybrid Bt strains. We attempted to do so using plasmid pHT:cry1Aa via electroporation.

PCR confirmation of the clones used in transformation

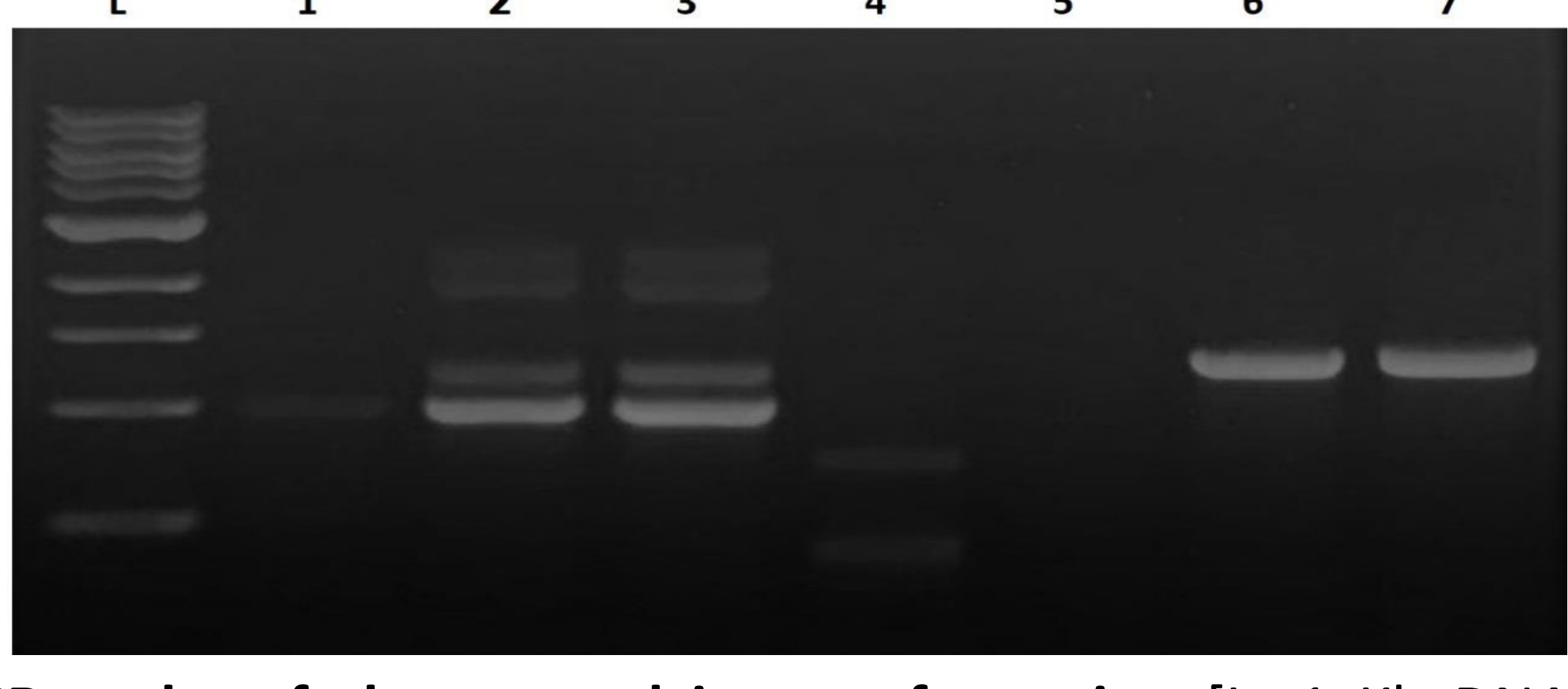

$\mathrm{PCR}$ reults of clones used in transformation

$\mathrm{H} 14$

Successful extraction of plasmid pHTtcrylAa from Bt and E.colt

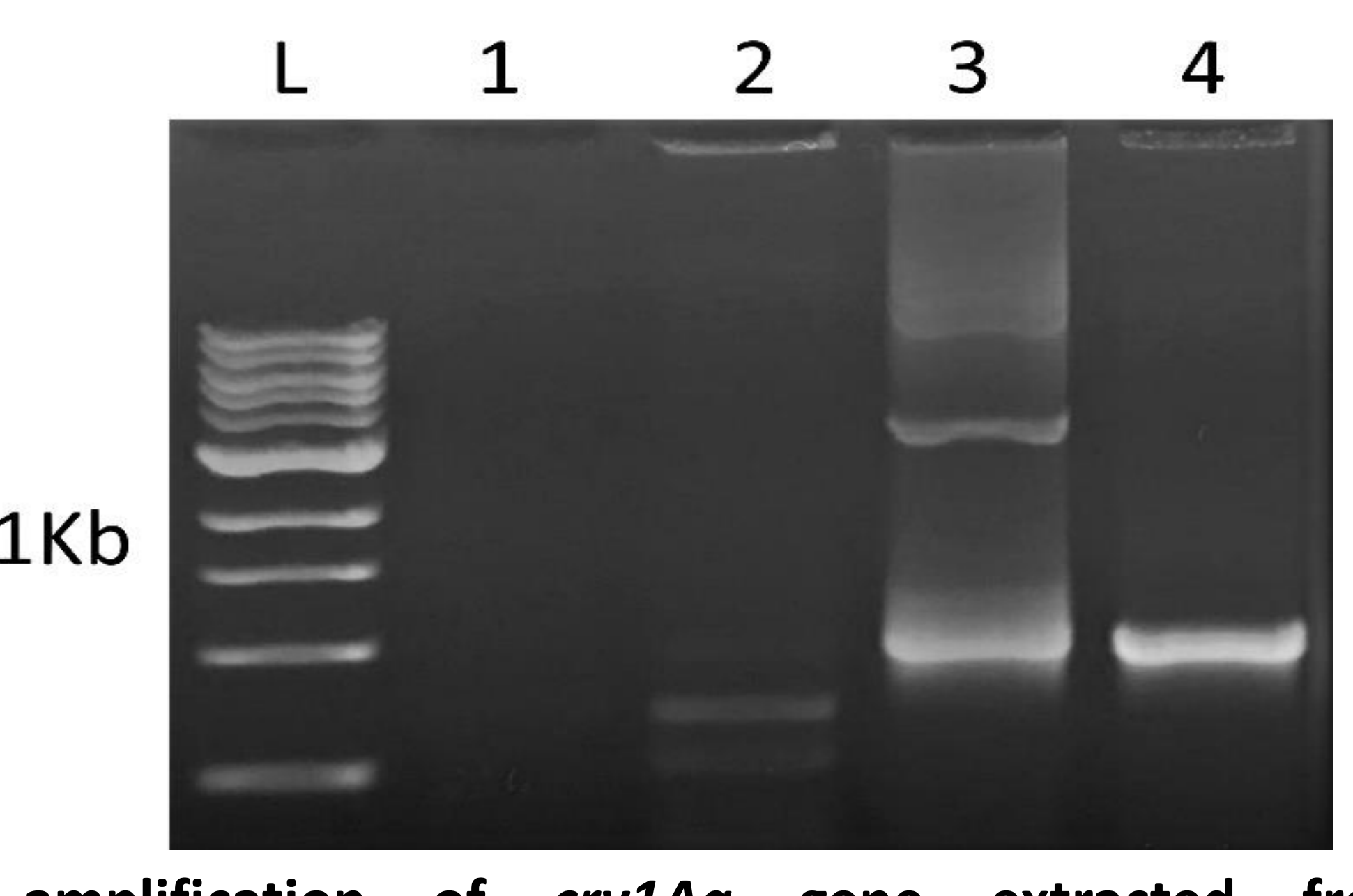

PCR amplification of cry1Aa gene extracted from transformed Bt and Escherichia coli (E.coli) bacteria as a first step to transform cured and non-cured $B t$ strains [ $L$ : 1

\section{from}

\section{Conclusion}

In the present work, we clearly demonstrated that

1- During cell growth, Bti strains lose the cry genes carrying plasmid pBtoxis much faster than Btk-corresponding plasmid.

2- Among Btk strains, QBT376 cryplasmid is almost as stable as that of HD1 reference strain. plasmid is less stable than the same plasmid in H14 reference strain. 4- The loss of plasmids directly affects other genes expression such as

protease coding genes evidenced in the present work.

5- Sporulation genes are not expressed upon exposing Bt strains to high temperature.

6- Cell morphology of Bti strains is changed upon exposure to high temperature.

These results will be directing us to explore the $\delta$-endotoxins content in the cured cry ${ }^{+}$mutants to give conclusive ideas about the effect of plasmid instability on $\delta$-endotoxin synthesis.

\section{Acknowledoments}

This publication was made possible by QU grant \#QUST-1- CAS 2020-12. The findings achievis of the authors. Special thanks to Ms. Randa Zedan.
3- Among Bti strains, QBT218 pBtoxis

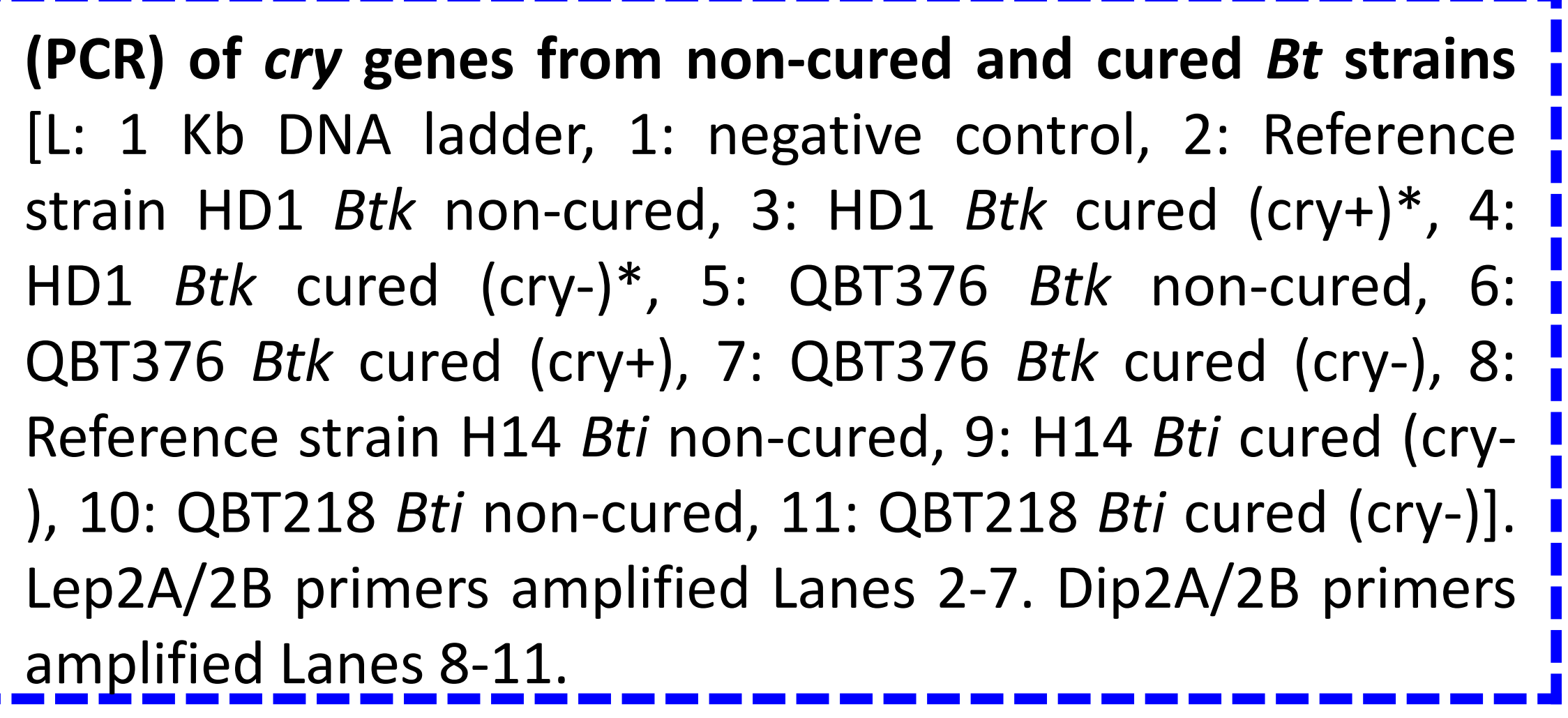

